\title{
MANAGEMENT ABILITIES OF PERSONALITY CULTURE MANAGER: THEORETICAL-EMPIRICAL ANALYSIS
}

\section{Martynyshyn Ya. M.}

\section{INTRODUCTION}

Of all the problems that people face in the course of society's historical development, obviously the most difficult is the man's nature and his abilities. This is especially true of the managerial ability, as the ability of the individual to lead other people, to direct their life.

The problem of managerial abilities is quite popular and at the same time extremely complicated. On the one hand, this problem is so widespread that there is no need to be a specialist in any narrow field to get involved by suggesting own approach. On the other hand, the problem of abilities in recent years has been filled with a large number of different research approaches: psychodynamic (S. Freud ${ }^{1}$ ), which focuses on unconscious mental and emotional motives, as the basis of the dynamics of human abilities development; ego-psychological (E. Erikson ${ }^{2}$, E. Fromm ${ }^{3}$, K. Horney ${ }^{4}$ ), based on the fact that the person's ego through life goes through several universal stages of biological maturation in interaction with the sphere of social relations, developing a certain system of abilities; dispositional (G. Allport ${ }^{5}$, R. Cattell ${ }^{6}, \mathrm{H}$. Eysenck $^{7}$ ), which especially emphasizes persistent qualities (human traits) that are inherent in the individual and ensure the constancy of his behavior over time and changing situations; behavioral (B. Skinner ${ }^{8}$ ), which is based on the fact that personality abilities are formed and developed under the influence of the external social environment and are the result of its observations of social models (parents, teachers, friends, successful people,

\footnotetext{
${ }^{1}$ Freud S. Group Psychology and the Analysis of the Ego. New York : W. W. Norton \& Company, 1990. $144 \mathrm{p}$.

${ }^{2}$ Erikson E. Identity and the Life Cycle Paperback. New York : W. W. Norton \& Company, 1994. 192 p.

${ }^{3}$ Fromm E. The Sane Society. London : Routledge, 2001. 426 p.

${ }^{4}$ Horney K. New Ways in Psychoanalysis. New York : W. W. Norton \& Company, 2000. 320 p.

${ }^{5}$ Allport G. The Person in Psychology. Boston : Beacon Press, 1968. 440 p.

${ }^{6}$ Cattell R. The Inheritance of Personality and Ability. New York : Academic Press, 1982. 449 p.

${ }^{7}$ Eysenck H. Personality, genetics, and behavior. New York : Praeger, 1982. 330 p.

${ }^{8}$ Skinner B. The Shaping of a Behaviorist. New York : University Press, 1985. 384 p.
} 
etc.) in order to adapt to the environment; social-cognitive (A. Bandura 9 , J. Rotter ${ }^{10}$ ), which emphasizes that a person's abilities are the result of a complex interaction between the cognitive processes of the individual and their influence on the external social environment; cognitive (G. Kelly ${ }^{11}$ ) assumes that the individual's ability is not a passive result of the influence of the external social environment on the person, and, above all, depends on the ability of the cognitive interpretation by the person of that environment; the humanist (A. Maslow ${ }^{12}$ ), who denies psychoanalysis and behaviorism and it is based on the fact that man is the creator of personal abilities and lifestyle; phenomenological (C. Rogers ${ }^{13}$ ), which focuses on the formation and development of abilities, the inner life of the individual: his vision, feeling, experience; synthetic (L. Hjelle \& D. Ziegler ${ }^{14}$ ), which was formed on the basis of developments generalizations within the previous approaches.

However, despite the academic weight of these and many other studies, they do not shed enough light on the major issues of management theory and practice in management. There is no clear answer to questions about the nature of abilities, their composition and structure, interconnections and interdependencies. The question of ability diagnostics remains open, especially in cases where it is not possible to assess what will happen in the near future based on past experience.

The more we know about the managers' capabilities, the more questions arise about what realities are behind this concept. That is why any study of managerial abilities carries the danger of answering any minor question, leaving aside the main complexities of the problem. This is especially true of the study of managerial abilities in poorly researched areas of social activity. Such an industry is, first of all, an area of Ukrainian culture where such research has hardly been conducted.

\section{The essence, composition and structure of managerial abilities}

Cultural management activities, like any other activity, can be characterized by different levels of its quality parameters, performed with greater or less efficiency. This is determined by many factors, but above all depends on manager's personal and professional qualities, the need for

\footnotetext{
${ }^{9}$ Bandura A. Psychological modelling. New York : Aldine-Atherton, 1974. 256 p.

${ }^{10}$ Rotter J. The development and applications of social learning theory. New York : Praeger. $367 \mathrm{p}$.

${ }^{11}$ Kelly G. The Psychology of Personal Constructs. London : Routledge, 1992. 470 p.

${ }^{12}$ Maslow A. Motivation and personality. New York : Harper and Row, 1987. 293 p.

${ }^{13}$ Rogers C. A Way of Being. Boston : Houghton Mifflin, 1980. 416 p.

${ }^{14}$ Hjelle L., Ziegler D. Personality Theories. New York : McGraw-Hill Publishing Co., 1992. 624 p.
} 
which is determined by the content and nature of management activities. In other words, the main factors for its effectiveness are specific managerial skills. Not only efficiency, but even the very possibility of implementation of managerial functions depends on whether or not a person possesses such abilities.

The practical significance of this problem is obvious and due to the fact that only on the basis of its solution it is possible to develop scientifically sound and constructive procedures for the selection of cultural managers, as well as their preparation ${ }^{15}$.

Difficulties in studying management skills in the field of culture are related to the fact that the very concept of abilities is one of the most complex in psychology and it is still not fully disclosed. It is constantly slipping away from the disclosure of its essence and dissolves in other psychological concepts: knowledge, skills, intelligence, personal qualities, mental processes, etc. However, today it has some general characteristics, the main provisions of which are as follows.

Abilities are the individual-psychological characteristics of the individual, which are the conditions for the successful implementation of any activity, revealing differences in the dynamics of mastering the knowledge, skills and skills necessary for it. There are such features that distinguish abilities from other psychic phenomena: first, abilities are individual psychological characteristics that distinguish one person from another; secondly, these are only those features that are relevant to the success of the activity; third, abilities are not limited to the knowledge, skills and skills that have already been developed in humans, although they determine the ease and speed of their acquisition.

Management abilities are characterized by two main aspects: qualitative and quantitative. Considering from the side of qualitative features, abilities are a difficult complex of a person's psychological properties, which ensure the success of the activity. Quantitative characteristic of abilities involves determining the extent of their expression, the ability development level ${ }^{16}$.

In the structure of the cultural manager's abilities, it is advisable to distinguish two of their main categories: they are general and special

\footnotetext{
${ }^{15}$ Обгрунтування парадигми менеджмент-освіти у соціокультурній сфері. За ред. Я. М. Мартинишина. Біла Церква : Вид. Пшонківський О.В., 2017. 509 с.

16 Мартинишин Я.М., Коваленко Є.Я. Мистецтво управління й освітні технології підготовки менеджерів соціокультурної діяльності. Біла Церква : Вид. Пшонківський О.В., 2018. С. 179-180.
} 
abilities. The former determine the success of many, not many, activities. The second is specific and determines the effectiveness of any particular activity. Abilities are formed and developed in the activity based on incomes. These are the morphological and functional features of the nervous system and the body as a whole, which act as natural and biologically conditioned, innate prerequisites for the abilities development.

Another starting and general position of the abilities psychology, in our opinion, it is the allocation of three qualitatively different levels of their presentation is actually abilities, talent (talent) and genius. In the theory of ability it is very important, but it has been still not resolved the question of the degree of inheritance, innate ability. Although, of course, abilities develop in ontogeny and first of all, under the influence of activity development, under the environmental factors influence, they also have a very strong hereditary dependence. The more general the ability is, the more genetically dependent and vice versa. The higher the level of inherited ability, the more likely it will be and the more it will develop not in spite of further living conditions, but in spite of them. Finally, abilities are not isolated entities, but inherent personality traits that interact with all other personal qualities. The abilities development is therefore inseparable from the individual development as a whole. They, influencing the nature of the personal qualities formation and personality as a whole, themselves experience the actions of the personality in the formation process. The abilities development and personality is a two-fold process. Thus the abilities concept finds its place in the general structure of psychological concepts. It is as if an intermediate link between two fundamental psychological concepts: activity and personality.

Extremely general status of the abilities concept, their inseparable connection both with activity, and with the personality cause difficulties of managerial abilities studying. The essence of these difficulties is as follows. Every cultural management activity has three main segments: 1) proper activity, organizational and administrative, connected with the organization of management of any cultural institution, as a system; 2) staffing is related to managing people, organizing interpersonal interactions; 3) production-creative, directly connected with the organization of creative-technological process, with its operational 
management ${ }^{17}$. Management effectiveness is determined by how well a manager is able to provide three of these different segments, as well as coordinate them with each other. The first it is an activity, organizational and administrative requires the development of general management skills and abilities, the ability to effectively organize joint activities. The second it is personnel, personal segment requires the availability of qualitatively other abilities that provide effective interpersonal interaction, organization and management of people. Such abilities will be played not by special or even general abilities, but by basic personal qualities. The third it is the production and creative segment involves the presence of the manager's professional qualities and his special abilities.

In addition, reconciling these three segments in the management process which requires another type of capability: a coordination, overall organizational plan, which again is linked to the manager's top personal qualities. Because of this content, the composition of management capabilities in the cultural sphere is very wide. They are not only properties that have professional specificity, but also many others, in fact, the head's personal qualities. Therefore, the question of managerial ability is often discussed in connection with the problem of the general structure of the leader's personality, and sometimes and they are replaced by it. The notion of abilities is identified with the personal qualities concept of the leader. This is the most characteristic feature of modern views on managerial abilities. As a result of this approach, the lists of managerial capabilities appear to be very extensive; they include very different in the degree of generalization and character traits of the psyche and the manager's personality.

This approach has the right to exist; it reflects the real complexity of management, the variety of requirements that it makes to the individual. In foreign psychology, it is developed into a "theory of traits" that contains extensive lists of such abilities, as well as in a number of other areas. However, this approach is referred to as collectible. It does not answer the question of what structure of management capabilities, how they are interconnected and what features of their organization. To better understand this really complex issue, let's note a number of groups of managerial qualities that are usually distinguished from their totality. They

\footnotetext{
${ }^{17}$ Мартинишин Я.М., Хлистун О.С. Ієрархія як феномен організаційної культури. Вісник Київського національного університету культури і мистецттв. Серія: Менеджмент соціокультурної діяльності. 2019. Вип. 1. С. 7-31.
} 
are either management capabilities in their own sense, or contribute to the effective execution of management activities.

First, it is a group of basic characteristics of the manager's personality, which is denoted by the concept of managerial characteristics. All of them are either necessary for management activity, or desirable for it, because they cause all things being equal and a high level of its success. In addition, they are also a factor that determines the preference for the personality of the choice of management activities, inclination to it. These characteristics are divided into two subgroups (Fig. 1). The first is the general social, so-called biographical characteristics inherent in an effective manager (socio-status, cultural, educational, gender-age, etc.). The second is the personal qualities of an effective manager (dominance, self-confidence, independence, striving for achievement, entrepreneurialism, emotional stability, stress resistance, responsibility, reliability, creativity, sociability).

Secondly, it is a group of managerial abilities. It includes only those features that directly and most significantly influence cultural management, as determined by its content and requirements. This group is most often regarded as a managerial capacity in the narrow sense. It is also divided into two subgroups. The first is the general organizational and psychological abilities (psychological selectivity, practical psychological reason, psychological tact, vigor, demandingness, criticality, inclination to organizational work). They determine the effectiveness of this type of activity as a whole. The second is the individual management capabilities that ensure the effective performance of individual management functions (goal setting, forecasting, planning, organizing, decision-making, motivation, communication, control and adjustment); solving partial, though important, management tasks.

Two of these groups are distinguished by the so-called activityfunctional criterion and by what properties of the psyche and personality quality are required for activity. However, in the management psychology, there is another criterion for the abilities' allocation, it is structural and psychological. According to it, the basis of ability allocation is not the structure and content of activity, and the structure of the psyche. According to this criterion, first, distinguish manifestations in the management of general and special abilities. Secondly, abilities are structured according to the main classes of mental processes: cognitive, regulatory, communicative. 


\begin{tabular}{|c|c|}
\hline \multicolumn{2}{|c|}{ Allocation of abilities by activity-functional criterion } \\
\hline $\begin{array}{l}\text { 1. Qualities that indirectly } \\
\text { implement functions } \\
\text { managerial abilities } \\
\text { (managerial characteristics) }\end{array}$ & \\
\hline $\begin{array}{l}\text { Personal qualities: } \\
\text { 1) dominance, confidence } \\
\text { in itself, independence, desire } \\
\text { to achievements and enterprise; } \\
\text { 2) emotional stability, } \\
\text { stress resistance; } \\
\text { 3) responsibility and reliability; } \\
\text { 4) creativity; } \\
\text { 5) sociability. }\end{array}$ & $\begin{array}{l}\begin{array}{l}\text { 2. Qualities that } \\
\text { are directly managerial } \\
\text { (manager's own ability) }\end{array} \\
\text { General organizational and } \\
\text { psychological abilities: } \\
\text { 1) psychological selectivity, } \\
\text { practical psychological } \\
\text { mind and psychological tact; } \\
\text { 2) energy; } \\
\text { 3) demanding and critical; } \\
\text { 4) propensity for organizing } \\
\quad \text { work } \\
\text { Local: } \\
\text { 1) laying unit; } \\
\text { 2) forecasting and planning; } \\
\text { 3) organizing; } \\
\text { 4) decision-making; } \\
\text { 5) motivation; } \\
\text { 6) communication; } \\
\text { 7) control and adjustment. }\end{array}$ \\
\hline \multicolumn{2}{|c|}{$\begin{array}{l}\text { Groups of managerial qualities } \\
\text { and the overall structure of the manager's abilities }\end{array}$} \\
\hline \multicolumn{2}{|c|}{$\begin{array}{l}\text { 3. The qualities that are the psychological basis of the first two groups, } \\
\text { which determine the level of their abilities development: }\end{array}$} \\
\hline 1) cognitive; 2) re & y; 3) communicative \\
\hline
\end{tabular}
Fig. 1. Groups of managerial qualities and general structure of abilities the personality of the cultural manager


Thus, the general structure of managerial abilities of the cultural manager should be based on the complementary use of two criteria, they are activity-functional and structural-psychological. As a result, there are three main groups of qualities that are either directly managerial abilities, or indirectly implement the functions of the manager's abilities (i.e., affect the management success and managerial characteristics). The third group there is the psychological basis for the first two, which determines the level of their abilities development.

\section{Statistical and mathematical study of managers' abilities and the success of cultural management}

The research methodology includes the following steps.

I. The statistics collection on the object of study, which involves surveying the staff of cultural institutions and quantifying their ability of managers of these institutions and their management's success:

$$
\left\{\mathrm{Z}_{i} ; \mathrm{U}\right\} \text {, }
$$

where $Z_{i}-$ level of ability of the $i$-th type, points; $U$ - management success, points.

The level of ability and management success is estimated on a 100-point scale. The research covers 39 cultural institutions in Ukraine, including: theaters are 13; concert organizations are 14; museums are 12 . The total number of respondents is 195 , of which representatives are: the theater sphere is 65; philharmonic are 67; museums are 63.

The following three groups of abilities are subject to evaluation:

1 group. Manager's personal qualities: 1) dominance, self-confidence, independence, aspiration for achievement and enterprise; 2) emotional stability, stress resistance; 3) responsibility and reliability; 4) creativity; 5) sociability.

2 group. General organizational and psychological abilities: 1) psychological selectivity, practical psychological reason and psychological tact; 2) energy; 3) demanding and critical; 4) propensity for organizational work.

3 group. The basic abilities that underlie the two previous groups of managerial abilities: 1) cognitive; 2) regulatory; 3) communicative.

II.Summary statistics and calculation of general indicators:

1) systematization of data by ability groups and types of cultural institutions; 
2) calculation of average values of ability indicators $\left(\check{Z}_{i}\right.$; $\left.\check{Z}\right)$ and success of managers ( $\breve{U})$ for each type of cultural institution and group of abilities:

$$
\check{Z}_{i}=\Sigma Z_{i} / \mathrm{N} ; \check{Z}=\Sigma \check{Z}_{i} / \mathrm{I} ; \check{\mathrm{U}}=\Sigma \mathrm{U} / \mathrm{N} \text {, }
$$

where $\mathrm{N}$ - number of respondents of a particular type of cultural institution;

I - the number of types of abilities in the group.

III. Building profiles of cultural managers' abilities based on the average values of their indicators:

$$
\left\{\check{Z}_{i}\right\} .
$$

IV. Drawing portraits capabilities theater, philharmonic and museum managers, reflecting their structural characteristics and features. The construction of these portraits is based on the distribution of all types of abilities by the appropriate level zones and subzones:

Abilities' high level:

- very high (professional) $\check{Z}_{i} \geq 91$;

- moderately high (elevated) $\check{Z}_{i}=81-90$;

Abilities' average level:

- upper average $\breve{Z}_{i}=71-80$;

- lower middle $\check{Z}_{i}=61-70$;

Low ability level:

- moderately low $\check{Z}_{i}=51-60$;

- very low $\check{Z}_{i} \leq 50$.

V. Analytical grouping of cultural institutions by the average level of managers' abilities $(\breve{Z})$ and identification of patterns of their influence on the management success $(\breve{U})$ :

$$
\check{Z} \rightarrow \text { Ŭ. }
$$

VI. Statistical and mathematical models development of management success depending on the level of mismatch of managers' abilities:

$$
\tilde{U}=\operatorname{Fc}\left(\Delta Z_{i}\right) \text {, }
$$

where $\tilde{U}$ - effective indicator of a model of a particular type of cultural institution (management success), in points; $\Delta Z_{i}$ - factor factors of the model (levels of discrepancy of manager's abilities), in points. Factor indicators are determined for each respondent and ability group by the following formula: 


$$
\Delta \mathrm{Z}_{i}=100-\mathrm{Z}_{i}
$$

where 100 - normative value of abilities, points.

Building models involves the following steps:

Step 1. Verification of aggregated and systematic statistical sample data for their compliance with the established requirements for statistical and mathematical modeling and representativeness. The results of such verification should show whether the information is sufficient, both in terms of number of units and variation of features, and in the consistency of its aggregates with normal distribution, and whether it is representative of the aggregate ${ }^{18}$.

The verification showed that the initial information is sufficient both in terms of the number of observation units $(\mathrm{N} / \mathrm{I} \geq 8)$ and the variation of the resultant and factor traits (var $>10 \%)$ and the agreement of its aggregates with the normal distribution $(\tau<3 \sigma)$; it is also representative of the general population since its actual error at a given probability level of 0.95 did not exceed the limit $(\Delta \mathrm{E}<\Delta \mathrm{Elim})$. Therefore, this selective information can be used to model the relationship between management success and managerial capacity mismatches, with the dissemination and interpretation of the results obtained across the entire cultural establishment in Ukraine (up to 3\% error).

Step 2. Identify the cause-effect relationship between factorial and resultant attributes, using grouping and graphical methods, and construct models in a general symbolic form.

As the analysis confirms, the relationship between the score (Ũ) and the factors $\left(\Delta \mathrm{Z}_{i}\right)$ is inverse, and the form of the relationship is close to linear. Therefore, the general view of the statistical and mathematical models will be as follows:

$$
\tilde{\mathrm{U}}=100-\Sigma a_{i} \Delta \mathrm{Z}_{i}
$$

where 100, $a_{i}$ - model parameters, in particular: 100 is free member (maximum value of management success); ai is regression coefficients.

More specifically, for each of the above three ability groups, the models will look like this:

$$
\begin{gathered}
\tilde{\mathrm{U}}=100-a_{1} \Delta \mathrm{Z}_{1}-a_{2} \Delta \mathrm{Z}_{2}-a_{3} \Delta \mathrm{Z}_{3}-a_{4} \Delta \mathrm{Z}_{4}-a_{5} \Delta \mathrm{Z}_{5} ; \\
\tilde{\mathrm{U}}=100-a_{1} \Delta \mathrm{Z}_{1}-a_{2} \Delta \mathrm{Z}_{2}-a_{3} \Delta \mathrm{Z}_{3}-a_{4} \Delta \mathrm{Z}_{4} ; \\
\tilde{\mathrm{U}}=100-a_{1} \Delta \mathrm{Z}_{1}-a_{2} \Delta \mathrm{Z}_{2}-a_{3} \Delta \mathrm{Z}_{3},
\end{gathered}
$$

where $a_{1} \ldots a_{5}$ - regression coefficients.

\footnotetext{
${ }^{18}$ Сріна А.М. Статистичне моделювання та прогнозування. Київ : КНЕУ, 2011. 170 с.
} 
Step 3. Modeling in numerical form. This work is done on a computer and includes correlation calculations and reliability evaluation of communication characteristics: the numerical values of the regression coefficients $\left(a_{i}\right)$, the multiple and partial correlation coefficients $\left(C, c_{i}\right)$ and determinations $\left(D, d_{i}\right)$, the actual values of the Fisher criteria $(F)$ and Student's $\left(t_{i}\right)$ are determined. Using the $t$ - and $F$-criteria you can estimate the reliability of the regression coefficients and the model as a whole. The correlation coefficients estimate the strength of the relationship and the coefficients of determination the proportion of variation in the productive trait, which is due to the influence of the factor traits.

VII. Statistical and mathematical analysis and forecasting. With the help of the developed numerical models it is possible to carry out a deep analysis of the management effectiveness (success). In particular, using the regression coefficients $\left(a_{i}\right)$, we determine the influence degree of the corresponding factor $\left(\Delta Z_{i}\right)$ on the resultant index ( $\left.\tilde{U}\right)$, in points: with the change of an individual factor per unit the resultant indicator will change to the corresponding coefficient. Knowing the magnitude of the variation of each factor, we find the maximum change in the resultant indicator, and by the coefficients of determination $\left(D, d_{i}\right)$ we conclude what proportion of its variation is explained by the influence of all or a single factor that is part of the model. Models can also be used to predict management success. Substituting the specific values of the factors-factors $\left(\Delta Z_{i}\right)$ into the model, we predict the expected values of the resultant indicator (U)

\section{Results and discussion.}

The main results of the study are presented in Tables $1-4$. The output, which builds on the following results, it is to build managers' ability profiles. As it can be seen from the tab. 1, the indicators of profiles by types of cultural institutions and groups of abilities are different. In some institutions they are very high, in others, on the contrary, very low, in others they are on average.

Among the personal qualities of cultural managers, philharmonic managers have the greatest dominance, confidence, independence, desire for achievement and enterprise, as well as emotional stability and stress resistance. The greatest responsibility, reliability and camaraderie are inherent in museum managers. The highest creativity is characteristic of theater managers, who also have high levels of dominance and entrepreneurship. 
In terms of general organizational and psychological abilities, philharmonic managers have the highest indicators of energy and aptitude for organizational work. Psychological selectivity, practical psychological reason and psychological tact are the best in museum managers, and the demanding and critical are theatrical managers.

Table 1

\section{Profiles of cultural managers' abilities}

\begin{tabular}{|c|c|c|c|}
\hline Abilities & Theaters & Philharmonic & Museums \\
\hline \multicolumn{4}{|c|}{1 group. Manager's personal qualities } \\
\hline $\begin{array}{l}\text { Dominance, self-confidence, } \\
\text { independence, striving for achievement } \\
\text { and entrepreneurship } \check{Z}_{1}\end{array}$ & 85 & 94 & 43 \\
\hline Emotional stability, stress resistance $\check{Z}_{2}$ & 46 & 83 & 51 \\
\hline Responsibility and reliability $Z_{3}$ & 64 & 48 & 77 \\
\hline Creativity $\check{Z}_{4}$ & 91 & 90 & 76 \\
\hline Sociability $\check{Z}_{5}$ & 61 & 58 & 70 \\
\hline \multicolumn{4}{|c|}{2 group. General organizational and psychological abilities } \\
\hline $\begin{array}{l}\text { Psychological selectivity, practical } \\
\text { psychological reason and psychological } \\
\text { tact } \check{Z}_{1}\end{array}$ & 76 & 51 & 78 \\
\hline Energy $\check{Z}_{2}$ & 60 & 90 & 45 \\
\hline Demand and criticality $\check{Z}_{3}$ & 92 & 59 & 61 \\
\hline Propensity for organizational work $\check{Z}_{4}$ & 45 & 95 & 75 \\
\hline \multicolumn{4}{|c|}{3 group. The basic abilities that underlie the previous ones } \\
\hline Cognitive $\check{Z}_{1}$ & 72 & 46 & 77 \\
\hline Regulatory $\check{Z}_{2}$ & 90 & 80 & 41 \\
\hline Communicative $\check{Z}_{3}$ & 41 & 92 & 65 \\
\hline
\end{tabular}

The highest values of basic abilities are also distributed differently between cultural institutions. Cognitive abilities prevail in museum managers, regulatory is in theatrical, and communicative is in the philharmonic. An even deeper analysis of the abilities of cultural managers can be made on the basis of portraits of abilities (Tab. 2).

From this analysis, the theatrical manager's abilities are almost evenly distributed between the high, middle and lower levels of the portrait (four abilities in each group). These managers have two abilities in the professional 
level: demanding and critical and creative. Regulatory, dominant and enterprising are also quite high. Communication skills, aptitude for organizational work, emotional stability and stress resistance are at the bottom. The average ability level of theater managers is 69 points.

Table 2

\section{Portraits of cultural managers' abilities}

\begin{tabular}{|c|c|c|}
\hline $\begin{array}{c}\text { Theatrical } \\
\text { manager }\end{array}$ & $\begin{array}{c}\text { Philharmonic } \\
\text { manager }\end{array}$ & $\begin{array}{l}\text { Museum } \\
\text { manager }\end{array}$ \\
\hline 1 & 2 & 3 \\
\hline \multicolumn{3}{|c|}{ High level of ability } \\
\hline \multicolumn{3}{|c|}{ Very high (professional) $\check{Z}_{i} \geq 91$} \\
\hline $\begin{array}{l}\text { Demand } \\
\text { and Criticality (92); } \\
\text { Creativity (91) }\end{array}$ & $\begin{array}{l}\text { Aptitude for } \\
\text { organizational work (95); } \\
\text { Dominance, self- } \\
\text { confidence, } \\
\text { independence, striving } \\
\text { for achievement and } \\
\text { entrepreneurship (94); } \\
\text { Communicative (92) }\end{array}$ & \\
\hline \multicolumn{3}{|c|}{ Moderately high (elevated) $\check{Z}_{i}=81-90$} \\
\hline $\begin{array}{l}\text { Regulability (90); } \\
\text { Dominance, self- } \\
\text { confidence, } \\
\text { independence, striving } \\
\text { for achievement and } \\
\text { entrepreneurship (85) } \\
\end{array}$ & $\begin{array}{l}\text { Creativity (90); } \\
\text { Energy (90); } \\
\text { Emotional stability, stress } \\
\text { resistance (83) }\end{array}$ & \\
\hline \multicolumn{3}{|c|}{ Average level of ability } \\
\hline \multicolumn{3}{|c|}{ The upper middle $\check{Z}_{i}=71-80$} \\
\hline $\begin{array}{l}\text { Psychological selectivity, } \\
\text { practical psychological } \\
\text { reason and psychological } \\
\text { tact (76); } \\
\text { Cognitive (72) }\end{array}$ & Regulatory (80) & $\begin{array}{l}\text { Psychological selectivity, } \\
\text { practical psychological } \\
\text { reason and psychological } \\
\text { tact (78); } \\
\text { Responsibility and } \\
\text { Reliability (77); } \\
\text { Cognitive (77); } \\
\text { Creativity (76); } \\
\text { Aptitude for } \\
\text { organizational work (75) }\end{array}$ \\
\hline
\end{tabular}


Table 2 (ending)

\begin{tabular}{|c|c|c|}
\hline 1 & 2 & 3 \\
\hline \multicolumn{3}{|l|}{ Lower average $\check{Z}_{i}=61-70$} \\
\hline $\begin{array}{l}\text { Responsibility } \\
\text { and reliability (64); } \\
\text { Sociability (61) }\end{array}$ & & $\begin{array}{l}\text { Sociability (70); } \\
\text { Communicativeness (65); } \\
\text { Demand } \\
\text { and Criticality (62) }\end{array}$ \\
\hline \multicolumn{3}{|l|}{ Low ability level } \\
\hline \multicolumn{3}{|l|}{ Moderately low $\check{Z}_{i}=51-60$} \\
\hline Energy (60) & $\begin{array}{l}\text { Demand } \\
\text { and Criticality (59); } \\
\text { Sociability (58); } \\
\text { Psychological selectivity, } \\
\text { practical psychological } \\
\text { reason and psychological } \\
\text { tact (51) }\end{array}$ & $\begin{array}{l}\text { Emotional stability, } \\
\text { stress resistance (51) }\end{array}$ \\
\hline \multicolumn{3}{|l|}{ Very low $\check{Z}_{i} \leq 50$} \\
\hline $\begin{array}{l}\text { Emotional stability, } \\
\text { stress resistance (46); } \\
\text { Aptitude for } \\
\text { organizational work (45); } \\
\text { Communicative (41) }\end{array}$ & $\begin{array}{l}\text { Responsibility and } \\
\text { reliability (48); } \\
\text { Cognitive (46) }\end{array}$ & $\begin{array}{l}\text { Energy (45); } \\
\text { Dominance, } \\
\text { self-confidence, } \\
\text { independence, striving } \\
\text { for achievement and } \\
\text { entrepreneurship (43); } \\
\text { Regulability (41) }\end{array}$ \\
\hline
\end{tabular}

Philharmonic managers' abilities are concentrated in the upper and lower portions of the portrait. In the middle zone, there is only one type of ability (regulatory). The higher zone includes six abilities: aptitude for organizational work, dominance, entrepreneurialism and communication (professional subzone); creativity, energy, emotional stability and stress resistance (moderately high subzones), which is a significant advantage of these managers among other cultural managers. At the lowest level there are cognitive abilities, responsibility and reliability, which is the weak point of this category of managers. The average ability of philharmonic managers is 74 points.

Unlike theater and philharmonic managers, museum managers do not have any top-level ability, which is their weakness. Another feature is that $2 / 3$ of their abilities are concentrated in the middle zone of the portrait (psychological selectivity, responsibility and reliability, cognitive, 
creativity, aptitude for organizational work, etc.) and only $1 / 3$ is in the lower zone (regulatory, dominant, energy, emotional stability and stress resistance). The average ability of museum managers is 63 points. All those abilities of managers in the lower and middle levels of the portrait need improvement. Their deviation from the standard is a reserve for improving the management efficiency. Therefore, they must be further developed to enhance the management skills in these areas. So, in particular, the communicative abilities development is very relevant for theatrical managers, the cognitive for the philharmonic, and the regulatory abilities for the museum managers.

Analytical grouping of cultural institutions by the level of managers' abilities confirms the existence of a regular direct correlation between the abilities indicators (the opposite between the indicators of deviation from the standard) and the success of management (Tab. 3).

The influence of managers' abilities on management success can be further analyzed and predicted on the basis of developed statistical and mathematical models (Tab. 4), which are sufficiently reliable for practical purposes, since the actual values of the $t$ and $F$ criteria were many times greater than the critical values. Multiple correlation coefficients of these models $(\mathrm{C}=-0.88 \ldots 0.90)$ indicate strong feedback between the resultant (U) and factor $\left(\Delta \mathrm{Z}_{i}\right)$ traits.

Table 3

Grouping of cultural institutions by the level of managers' abilities and identifying their impact on management success

\begin{tabular}{|c|c|c|c|c|c|}
\hline \multicolumn{2}{|c|}{ Theaters } & \multicolumn{2}{c|}{ Philharmonic } & \multicolumn{2}{c|}{ Museums } \\
\hline$[\check{Z}]$ & Ǔ & {$[\check{Z}]$} & $\check{U}$ & {$[\check{Z}]$} & U \\
\hline$\leq 60$ & 54 & $\leq 60$ & 59 & $\leq 60$ & 52 \\
\hline $61-80$ & 71 & $61-80$ & 76 & $61-80$ & 70 \\
\hline$\geq 81$ & 95 & $\geq 81$ & 98 & $\geq 81$ & 91 \\
\hline Average & 75 & Average & 80 & Average & 67 \\
\hline
\end{tabular}

With the change of a certain factor to $+/-\Delta Z_{i}$, the resultant index will change by the value of the product of this change and the corresponding regression coefficient $\left(a_{i}\right)$, i.e.:

$$
\Delta \tilde{\mathrm{U}}_{i}=-/+\Delta \mathrm{Z}_{i} \cdot a_{i} .
$$


For example, by increasing the cognitive ability of managers by 10 points, which means reducing the mismatch of this type of abilities by 10 points $\left(\Delta Z_{1}=-10\right)$, the success of managing theater, philharmonic and museum managers will increase, on average, by: $\Delta \tilde{U}_{1}=(-10)$. $(-0.334)=3.34 ; \Delta \tilde{U}_{1}=(-10) \cdot(-0.169)=1.69 ; \Delta \tilde{U}_{1}=(-10) \cdot(-0.508)=5.08$ points.

We have considered only one of the possible combinations of changing cultural managers' abilities, but there may be a lot and at most different types of cultural institutions and ability groups. For example, by reducing the inconsistency of theatrical managers' abilities in the group of general organizational and psychological abilities according to the above four factors (psychological selectivity $\Delta Z_{1}$, vigor $\Delta Z_{2}$, demanding and criticality $\Delta Z_{3}$, tendency to organizational work $\Delta Z_{4}$ ), respectively, by 15 , $20,4,25$, the success of management at the expense of each of them will increase accordingly by: $\Delta \tilde{\mathrm{U}}_{1}=15 \cdot 0.296=4.4 ; \quad \Delta \tilde{\mathrm{U}}_{2}=20 \cdot 0.189=3.8$; $\Delta \tilde{\mathrm{U}}_{3}=5 \cdot 0.377=1.9 ; \quad \Delta \tilde{\mathrm{U}}_{4}=25 \cdot 0.138=3.5$ points; and a total of $\Delta \tilde{\mathrm{U}}=13.6$ points. The predicted management success in theaters will be $\tilde{\mathrm{U}}=\breve{U}+\Delta \tilde{\mathrm{U}}=75+13.6=88.6$ points.

Table 4

\section{Statistical and mathematical models of management success depending on the managers' ability level}

\begin{tabular}{|l|c|}
\hline $\begin{array}{c}\text { Cultural } \\
\text { institutions }\end{array}$ & \multicolumn{1}{c|}{ Models and their characteristics } \\
\hline \multicolumn{1}{|c|}{1} & \multicolumn{1}{c|}{ 1 group. The manager's personal qualities } \\
\hline \multicolumn{3}{|c|}{ Theaters } & $\begin{array}{l}\tilde{\mathrm{U}}=100-0.254 \Delta \mathrm{Z}_{1}-0.108 \Delta \mathrm{Z}_{2}-0.212 \Delta \mathrm{Z}_{3}-0.292 \Delta \mathrm{Z}_{4}-0.134 \Delta \mathrm{Z}_{5} \\
\mathrm{C}=-0.88 ; \mathrm{D}=0.77 ; \mathrm{d}_{1}=0.20 ; \mathrm{d}_{2}=0.08 ; \mathrm{d}_{3}=0.16 ; \mathrm{d}_{4}=0.22 ; \mathrm{d}_{5}=0.11\end{array}$ \\
\hline Philharmonic & $\begin{array}{l}\tilde{\mathrm{U}}=100-0.281 \Delta \mathrm{Z}_{1}-0.204 \Delta \mathrm{Z}_{2}-0.137 \Delta \mathrm{Z}_{3}-0.263 \Delta \mathrm{Z}_{4}-0.115 \Delta \mathrm{Z}_{5} \\
\mathrm{C}=-0.89 ; \mathrm{D}=0.79 ; \mathrm{d}_{1}=0.22 ; \mathrm{d}_{2}=0.16 ; \mathrm{d}_{3}=0.11 ; \mathrm{d}_{4}=0.21 ; \mathrm{d}_{5}=0.09\end{array}$ \\
\hline \multirow{2}{*}{ Museums } & $\begin{array}{l}\tilde{\mathrm{U}}=100-0.126 \Delta \mathrm{Z}_{1}-0.139 \Delta \mathrm{Z}_{2}-0.287 \Delta \mathrm{Z}_{3}-0.254 \Delta \mathrm{Z}_{4}-0.194 \Delta \mathrm{Z}_{5} \\
\mathrm{C}=-0.88 ; \mathrm{D}=0.78 ; \mathrm{d}_{1}=0.10 ; \mathrm{d}_{2}=0.11 ; \mathrm{d}_{3}=0.22 ; \mathrm{d}_{4}=0.20 ; \mathrm{d}_{5}=0.15\end{array}$ \\
\hline Theaters & group. General organizational and psychological abilities \\
\hline \multirow{2}{*}{ Philharmonic } & $\begin{array}{l}\tilde{\mathrm{U}}=100-0.296 \Delta \mathrm{Z}_{1}-0.189 \Delta \mathrm{Z}_{2}-0.377 \Delta \mathrm{Z}_{3}-0.138 \Delta \mathrm{Z}_{4} \\
\mathrm{C}=-0.90 ; \mathrm{D}=0.81 ; \mathrm{d}_{1}=0.24 ; \mathrm{d}_{2}=0.15 ; \mathrm{d}_{3}=0.31 ; \mathrm{d}_{4}=0.11\end{array}$ \\
\hline \multirow{2}{*}{$\begin{array}{l}\tilde{\mathrm{U}}=100-0.154 \Delta \mathrm{Z}_{1}-0.312 \Delta \mathrm{Z}_{2}-0.189 \Delta \mathrm{Z}_{3}-0.345 \Delta \mathrm{Z}_{4} \\
\text { Museums }\end{array}$} & $\begin{array}{l}\tilde{\mathrm{U}}=100-0.325 \Delta \mathrm{Z}_{1}-0.158 \Delta \mathrm{Z}_{2}-0.273 \Delta \mathrm{Z}_{3}-0.244 \Delta \mathrm{Z}_{4} \\
\mathrm{C}=-0.89 ; \mathrm{D}=0.80 ; \mathrm{d}_{1}=0.26 ; \mathrm{d}_{2}=0.13 ; \mathrm{d}_{3}=0.22 ; \mathrm{d}_{4}=0.19\end{array}$ \\
\hline
\end{tabular}


Table 4 (ending)

\begin{tabular}{|l|l|}
\hline \multicolumn{1}{|c|}{1} & \multicolumn{1}{c|}{2} \\
\hline \multicolumn{2}{|c|}{ 3 group. The basic abilities that underlie the previous ones } \\
\hline \multirow{2}{*}{ Theaters } & $\tilde{U}=100-0.334 \Delta \mathrm{Z}_{1}-0.485 \Delta \mathrm{Z}_{2}-0.181 \Delta \mathrm{Z}_{3}$ \\
& $\mathrm{C}=-0.88 ; \mathrm{D}=0.78 ; \mathrm{d}_{1}=0.26 ; \mathrm{d}_{2}=0.38 ; \mathrm{d}_{3}=0.14$ \\
\hline \multirow{2}{*}{ Philharmonic } & $\tilde{\mathrm{U}}=100-0.169 \Delta \mathrm{Z}_{1}-0.384 \Delta \mathrm{Z}_{2}-0.447 \Delta \mathrm{Z}_{3}$ \\
& $\mathrm{C}=-0.89 ; \mathrm{D}=0.80 ; \mathrm{d}_{1}=0.13 ; \mathrm{d}_{2}=0.31 ; \mathrm{d}_{3}=0.36$ \\
\hline \multirow{2}{*}{ Museums } & $\tilde{U}=100-0.508 \Delta \mathrm{Z}_{1}-0.147 \Delta \mathrm{Z}_{2}-0.345 \Delta \mathrm{Z}_{3}$ \\
& $\mathrm{C}=-0.88 ; \mathrm{D}=0.77 ; \mathrm{d}_{1}=0.39 ; \mathrm{d}_{2}=0.11 ; \mathrm{d}_{3}=0.27$ \\
\hline
\end{tabular}

With the decrease in the same size of abilities of philharmonic and museum managers, the management success in philharmonic and museums will increase respectively by $18.1,15.5$ points and will make $98.1,82.5$ points, respectively.

Similar predictive calculations can be made for other ability groups with a variety of factor combinations.

\section{CONCLUSIONS}

The research results allow us to reach the following conclusions:

1. Existing methodological approaches (psychodynamic, egopsychological, dispositional, behavioral, social-cognitive, cognitive, humanistic, phenomenological, synthetic, etc.) do not give a definite answer about the nature, composition, structure, interconnections and management interdependencies. This is especially true of cultural management.

2. The manager's abilities, they are individual psychological characteristics, which are the conditions for successful management. They are formed in the process of activity on the basis of natural inclinations and develop in ontogeny and under the influence of mastering the practice of management and environmental factors.

3. Managerial ability is the intermediate link between the activity and the manager's personality. Therefore, in determining the composition of the cultural manager's capabilities, it is necessary to proceed from the structure of his activity, which includes the following segments: organizational and administrative, which requires developed general management skills; a staff who needs interpersonal skills; creative and production that desires special abilities of work in a certain field of culture.

4. It has been proved that the most accurate structure of the cultural manager's abilities can be determined on the basis of activity-functional 
and structural-psychological criteria. On this basis, there are three main groups of manager qualities that are either directly managerial, or indirectly implement the functions of ability. The third group is the psychological basis for the first two.

5 . With the help of the offered statistical and mathematical tools it is possible to carry out a deep quantitative analysis of abilities indicators and management efficiency, as well as to simulate and predict the interdependence of these indicators in the theatrical, philharmonic and museum branches of culture in Ukraine.

The obtained results are new and can be used to identify reserves for improving the performance of cultural managers and developing strategies for improving their training and skills development in the development and development of relevant capabilities.

\section{SUMMARY}

The problem of managerial abilities of cultural managers is being considered. Particular attention is paid to the psychological features of the managerial abilities nature, their composition, structure and interdependencies. The results of empirical research aimed at revealing the current level of managerial abilities development of cultural managers in relation to their management success are presented. A mathematical and mathematical toolkit has been offered, which allows to carry out a deep quantitative analysis of abilities' indicators and management efficiency, as well as to carry out modeling and forecasting the interdependence of these indicators in the theatrical, philharmonic and museum branches in Ukrainian culture.

\section{REFERENCES}

1. Freud S. Group Psychology and the Analysis of the Ego. New York: W.W. Norton \& Company, 1990. 144 p.

2. Erikson E. Identity and the Life Cycle Paperback. New York : W.W. Norton \& Company, 1994. 192 p.

3. Fromm E. The Sane Society. London : Routledge, 2001. 426 p.

4. Horney K. New Ways in Psychoanalysis. New York : W.W. Norton \& Company, 2000.320 p.

5. Allport G. The Person in Psychology. Boston : Beacon Press, 1968. $440 \mathrm{p}$.

6. Cattell R. The Inheritance of Personality and Ability. New York : Academic Press, 1982. 449 p. 
7. Eysenck H. Personality, genetics, and behavior. New York : Praeger, $1982.330 \mathrm{p}$.

8. Skinner B. The Shaping of a Behaviorist. New York : University Press, 1985.384 p.

9. Bandura A. Psychological modelling. New York : Aldine-Atherton, 1974. $256 \mathrm{p}$.

10. Rotter J. The development and applications of social learning theory. New York : Praeger. $367 \mathrm{p}$.

11. Kelly G. The Psychology of Personal Constructs. London : Routledge, 1992. $470 \mathrm{p}$.

12. Maslow A. Motivation and personality. New York : Harper and Row, 1987. 293 p. $416 \mathrm{p}$.

13. Rogers C.A Way of Being. Boston : Houghton Mifflin, 1980.

14. Hjelle L., Ziegler D. Personality Theories. New York : McGrawHill Publishing Co., 1992. 624 p.

15. Обгрунтування парадигми менеджмент-освіти у соціокультурній сфері. За ред. Я.М. Мартинишина. Біла Церква : Вид. Пшонківський О.В., 2017. 509 с.

16. Мартинишин Я.М., Коваленко Є.Я. Мистецтво управління й освітні технології підготовки менеджерів соціокультурної діяльності. Біла Церква : Вид. Пшонківський О. В., 2018. 374 с.

17. Мартинишин Я.М., Хлистун О.С. Ієрархія як феномен організаційної культури. Вісник Київського національного університету культури і мистецтв. Серія: Менеджмент соиіокультурної діяльності. 2019. Вип. 1. С. 7-31.

18. Сріна А.М. Статистичне моделювання та прогнозування. Київ : КНЕУ, 2011. 170 с.

Information about the author: Martynyshyn Ya. M.

Doctor of Economics, Professor, Professor at the Department of Show Business Management of the Kyiv National University of Culture and Arts 36, Eugene Konovalets str., Kyiv, 01601, Ukraine 